et al. (1971) noted that electron-dense deposits in electronmicrographs were usually on the "endothelial surface of the glomerular capillary wall." Such lesions were clearly not among those we saw.

With regard to the relationship between Q.M.N. and the tropical nephropathy seen in Senegal the similarities lie in the histological features rather than in the immunofluorescence findings. Thus in both conditions a fibrillary change in the capillary wall leads to focal and segmental glomerulosclerosis. Moreover, electronmicrographs show intrusion of basementmembrane-like material into the capillary lumen, which was one of the lesions that White (1973) stressed in Q.M.N. He also reported the presence of curious lacunar areas of basement membrane resorption, at the centre of which were electrondense flecks. These were not noted in the study of Q.M.N. made by Allison etal. (1971), though they described conspicuous electron-dense deposits within the glomerular basement membrane in 12 out of 14 cases, deposits which were not seen by White.

In short, the two unusual nephropathies we observed in Senegal differed, despite some similarities, from others hitherto reported in West Africa. One was a form of extramembranous glomerulonephritis characterized by hypocomplementaemia in the absence of evidence of systemic lupus erythematosus. No cause could be found for this nephropathy though it appeared to have an immune basis. In this respect it differed from the second and commoner condition which we term tropical nephropathy. No single cause of this condition was apparent, and, in particular, evidence of malaria was lacking in many instances; yet it had morphological features similar to those seen in cases described in Nigeria as Q.M.N. The most obvious morphological change common to Q.M.N. and tropical nephropathy was the curious fibrillary thickening and narrowing of the glomerular capillaries. Possibly this change is a primary abnormality in African children, an abnormality capable in various circumstances of trapping circulating micro-organisms, parasites, and immune complexes.

Our thanks are due to Dr. Christopher Draper, of the London School of Hygiene and Tropical Medicine, for his help with the study of malaria antibodies, and to Denise Bowes and Jill Vinter for their help with the electron microscopy.

\section{Addendum}

Dr. D. Wright, of the Department of Microbiology, Charing Cross Hospital Medical School, has provided serological evidence of treponemal infection-for example, Yaws or Syphilis-in two cases of tropical nephropathy (nos. 12 and 13) and in one of extramembranous glomerulonephritis (case 20 (ii)) but not in nine others tested (cases 4, 5 (ii), 10, 14, 15, 18 (ii), 19 (ii), 21, and 26). Thus in cases 12,13 , and 20 (ii) the treponemal haemagglutination test gave a positive result, as did the V.D.R.L. (modified Wassermann) agglutination test at titres of $1 / 32,1 / 8$, and $1 / 1$. The fluorescent treponemal antibody test was positive in case 13 . None of the 12 sera reacted with the indirect immunofluorescent technique against cercariae of $S$. haematobium.

\section{References}

Allison, A. C., et al. (1971). Bulletin of the World Health Organization, 46, 387. Cited in W.H.O. memorandum.

Andres, G. A., et al. (1970). Fournal of Clinical Investigation, 49, 2106.

Berger, J., et al. (1967). Actuolités Néphrologiques de l'Hôpital Necker, p. 161. Bhamarapravati, N., et al. (1973). Archives of Pathology, 96, 289.

Churg, J., Habib, R., and White, R. H. R. (1970). Lancet, 1, 1299.

Edington, G. M., and Mainwaring, A. R. (1966). In The kidney: International Academy of Pathology Monographs, No. 6, ed. F. K. Mostof $\mathrm{i}$ and D. E. Academy of Pathology Monographs, No. 6, ed. F.
Smith, p. 488. Baltimore, Williams and Wilkins.

Gewurz, H., ot al. (1968). International Archives of Allergy, 34, 556.

Giglioli, G. (1962 a). Annals of Tropical Medicine and Parasitology, 56, 101. Giglioli, G. (1962 b). Annals of Tropical Medicine and Parasitology, 56, 225. Gilles, H. M., and Hendrickse, R. G. (1963). British Medical Fournul, 2, 27. Habib, R. 1973). In Glomerulonephritis, Proceedings of an International Symposium, ed. P. Kincaid-Smith, T. H. Mathew, and E. L. Becker, vol. 1, p. 22. New York, Wiley.

Habib, R., Kleinknecht, C., and Royer, P. (1971). Archives Françaises de Pédiatrie, 28, 277 .

Hendrickse, R. G., et al. (1972). Lancet, 1, 1143.

Houba, V., et al. (1970). In Proceedings of International Symposium on Immune Complex Diseases, ed. L. Bonomo and J. L. Turk, p. 23. Milan, Carlo Erba Foundation.

Houba, V., et al. (1971). Clinical and Experimental Immunology, 8, 761

Kibukamusoke, J. W., Hutt, M. S. R., and Wilks, N. E. (1967). Quarterly fournal of Medicine, 36, 393 .

Morel-Maroger, L., Leathem, A., and Richet, G. (1972). American fournal of Medicine, 53, 170.

Morel-Maroger, L. J., et al. (1973). Comptes Rendus Hebdomadaires des Séances de l'Académie des Sciences, 276, Ser. D, p. 2477.

Paillerets, F. de, et al. (1972). Guigoz Scientific Review, 89, 2 .

Rothfield, ., et al. (1972). New England Fournal of Medicine, 287, 681

Satgé, P., et al. (1970). Annales de Pédiatrie, 17, 382.

Voller, A., Davies, D. R., and Hutt, M. S. R. (1973). British fournal of Experimental Pathology, 54, 457.

White, R. H. R. (1973). Nephron, 11, 147.

Wing, A. J., Kibukamusoke, J. W., and Hutt, M. S. R. (1971). Transactions of the Royal Society of Tropical Medicine and Hygiene, 65, 543.

\title{
Serum Ferritin Assay and Iron Status in Chronic Renal Failure and Haemodialysis
}

\author{
S. HUSSEIN, J. PRIETO, M. O'SHEA, A. V. HOFFBRAND, R. A. BAILLOD, J. F. MOORHEAD
}

British Medical fournal, 1975, 1, 546-548

\section{Summary}

Forty-four patients with chronic renal failure on haemodialysis for four months to eight years were studied. All received intravenous iron dextran $100 \mathrm{mg}$ on alternate

\section{Royal Free Hospital, London NW3 2QG}

S. HUSSEIN, M.D., Lecturer in Haematology

J. PRIETO, M.D. Associate Professor of Medicine (Present address: Catedro de Patologia General, Facultad de Medicina, Valladolid, Spain)

M. O'SHEA, M.D., M.R.C.PATH. Consultant Haematologist (Present address: M. O'SHEA, M.D., M.R.C.PATH. Consultant Haematologist (Present a A. V. HOFFBRAND, D.M., M.R.C.PATH., Professor of Haematology R. A. BAILLOD, M.B., B.S., Medical Assistant in Nephrology J. F. MOORHEẢD, F.R.c.P., Consultant Nephrologist weeks. Serum ferritin concentrations correlated well with body iron stores estimated by grading the bone marrow stainable iron. Altogether 34 patients showed increased bone marrow iron stores and serum ferritin concentrations greater than controls; four patients showed absence of iron in the marrow, and three of these had subnormal serum ferritin concentrations. Serum ferritin assay represents the best method of repeatedly monitoring the exact amount of iron therapy needed by patients with chronic renal failure, particularly those on regular haemodialysis.

\section{Introduction}

A sensitive immunoradiometric assay of serum ferritin has been described (Addison et al., 1972) and a good correlation found 
between the serum ferritin concentration and total body iron stores in patients with iron deficiency and iron overload (Jacobs et al., 1972). In normal people the serum ferritin concentration is also related to the amount of mobilizable iron as measured by repeated phlebotomy (Walters et al., 1973).

Iron deficiency is common in patients on maintenance haemodialysis (Crockett et al., 1968; Wright et al., 1969). It is difficult, however, to assess exactly the need for iron therapy or to decide how much iron each patient needs prophylactically because iron loss varies greatly from one patient to the next. Moreover, it is difficult to assess the iron status of these patients because the degree of anaemia depends on several other factors, while transferrin saturation is an unsatisfactory index of the state of the total body iron stores in renal failure. The bone marrow stainable iron is the most useful guide to the need for iron therapy (Edwards et al., 1970) but repeated bone marrow aspiration is clearly undesirable.

We have shown an excellent correlation between the serum ferritin concentration and the bone marrow iron appearance in 44 patients with chronic renal failure on maintenance haemodialysis. Estimation of serum ferritin, therefore, probably represents the best method of assessing the need for iron in renal failure.

\section{Subjects and Methods}

Of the 44 patients studied ( 29 male and 15 female) 22 had been on dialysis four months to four years, 19 for four to seven years, and 3 for up to eight years. The patients had an external arteriovenus shunt or an arteriovenous fistula. They were dialysed at home thrice weekly for a total of 30 hours using the Kiil dialyser (Moorhead et al., 1970). At least $4 \mathrm{ml}$ of blood is lost with each dialy sis. A careful patient probably loses less than $100 \mathrm{ml}$ of blood a month but may lose as much as $240 \mathrm{ml} ; 15 \mathrm{ml}$ is also lost to the laboratory each month for investigations.

Until 1966 patients received blood transfusion, but since then intravenous iron dextran (Imferon) $100 \mathrm{mg}$ has been selfadministered on alternate weeks. A few patients admitted missing an occasional dose. After 1966 blood transfusions were given only for acute blood loss not due to dialysis or for severe anaemia which did not respond to other haematinics; 18 of the patients received blood transfusions, which ranged from 1 to 25 units (see table). All patients also received folic acid $5 \mathrm{mg}$, cyanocobalamin $250 \mu \mathrm{g}$, and the contents of one pair of Parentrovite ampoules intravenously on alternate weeks together with ascorbic acid $50 \mathrm{mg}$ thrice daily and Multivite 1 tablet thrice daily. A total of 13 male and 15 female healthy adult hospital staff had blood samples taken for the estimation of serum ferritin.

Haematological studies included haemoglobin, packed cell volume, reticulocyte count (Dacie and Lewis, 1963), serum iron, total iron-binding capacity, serum ferritin, and sternal bone marrow biopsy. Serum iron and total iron-binding capacity were measured according to the reference method recommended by the International Committee for Standardisation in Haematology. The normal range for serum iron is $14-32 \mu \mathrm{mol} / 1(80-180 \mu \mathrm{g} / 100 \mathrm{ml})$ and for total iron-binding capacity 45-70 $\mu \mathrm{mol} / 1(250-400 \mu \mathrm{g} / 100$ $\mathrm{ml}$ ). Serum ferritin was measured by the method of Addison et al. (1972). Bone marrow films were stained for iron (Peris's stain) and iron stores were graded by one observer as follows: 0 , no stainable iron; I (normal), faint, diffuse, or slightly coarser staining with some granules; II (increased), coarser staining with dense granules; and III (greatly increased), gross macrophage and free iron rhrsuring cell morphology in marrow particles.
Results

The hasmoglobin concentrations of the 44 patients ranged from 43 to $16.0 \mathrm{~g} / \mathrm{dl}$ (see table). All the patients were anaemic except one male patient with polycystic disease. Of the remaining patients 42 had a normocytic normochromic anaemia, and one male patient had a hypochromic microcytic anaemia (haemoglobin $5.9 \mathrm{~g} / \mathrm{dl}$ ). Four patients showed no stainable bone marrow iron. Of the remainder the bone marrow iron stores were normal in six, increased in 28 , and greatly increased in six. Twelve of the 40 patients with normal or increased storage (macrophage) iron showed no or virtually no stainable iron in the developing erythroblasts.

The mean serum ferritin concentration in the 13 normal men was $188 \mu \mathrm{g} / 1$ (range $110-330 \mu \mathrm{g} / 1$ ) and in the 15 normal women $58 \mu \mathrm{g} / 1$ (range 15-135 $\mu \mathrm{g} / 1$ ) (see fig.). In the 44 patients there was a good correlation between the serum ferritin concentrations and the bone marrow stores (fig.). Serum ferritin

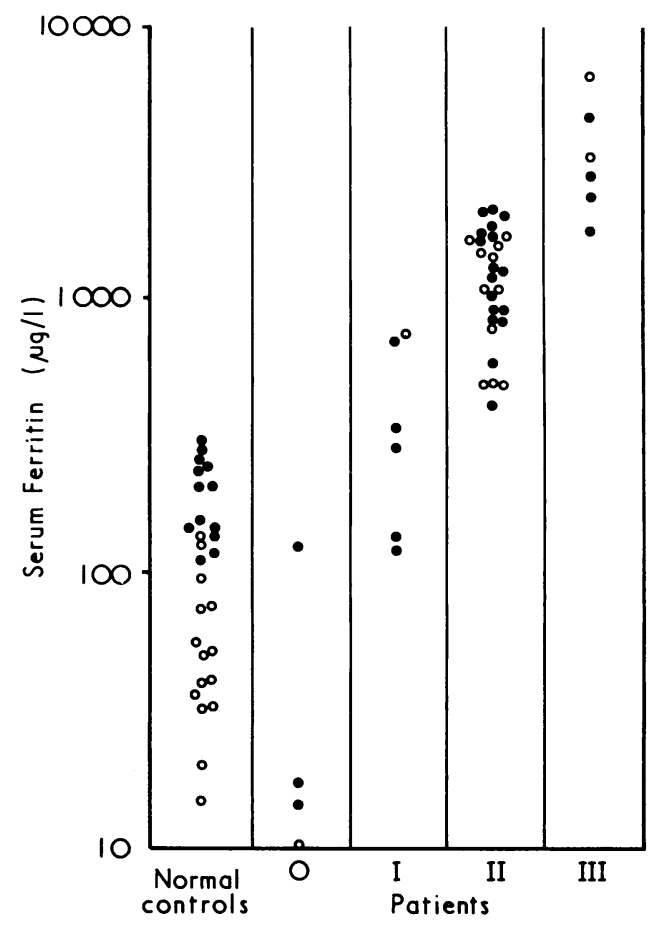

Relation between serum ferritin concentration and bone marrow iron stores in normal subjects and patients (bone marrow iron stores graded 0-III; see text). $0=$ Female. $=$ Male.

was normal in one patient with grade 0 bone marrow iron stores and in four of the six with normal iron stores. The serum ferritin concentration was raised in all the other patients, including two with normal bone marrow iron stores and all 34 patients with grades II and III bone marrow iron stores.

On the other hand, there was no correlation between serum iron, total iron-binding capacity, or percentage transferrin saturation and bone marrow iron stores or serum ferritin concentrations. Patients who received intravenous iron dextran a

Details of Cases

\begin{tabular}{|c|c|c|c|c|c|c|c|c|c|}
\hline \multicolumn{2}{|c|}{ No. of Patients } & \multirow{2}{*}{$\begin{array}{l}\text { Mean age } \\
\text { in Years } \\
\text { (Range) }\end{array}$} & \multirow{2}{*}{$\begin{array}{l}\text { Mean } \\
\text { Duration of } \\
\text { Treatment } \\
\text { in Months } \\
\text { (Range) }\end{array}$} & \multirow{2}{*}{$\begin{array}{c}\text { Mean No. of } \\
\text { Units of } \\
\text { Blood } \\
\text { Transfused } \\
\text { (Range) }\end{array}$} & \multirow{2}{*}{$\begin{array}{l}\text { Mean } \mathrm{Hb} \\
\text { Concentration } \\
\text { in } \mathrm{g} / \mathrm{dl} \\
(\text { Range })\end{array}$} & \multirow{2}{*}{$\begin{array}{l}\% \text { Mean } \\
\text { Reticulocyte } \\
\text { Count } \\
\text { (Range) }\end{array}$} & \multirow{2}{*}{$\begin{array}{c}\text { M.C.H.C. in } \\
\text { g/di } \\
\text { (Range) }\end{array}$} & \multirow{2}{*}{$\begin{array}{l}\text { Mean Serum } \\
\text { Ferritin Level } \\
\text { in } \mu \mathrm{g} / \mathrm{l} \\
\text { (Range) }\end{array}$} & \multirow{2}{*}{$\begin{array}{l}\text { Bone Marrow } \\
\text { Iron Store } \\
\text { Grade }\end{array}$} \\
\hline M. & F. & & & & & & & & \\
\hline $\begin{array}{r}3 \\
5 \\
17 \\
4\end{array}$ & $\begin{array}{r}1 \\
1 \\
11 \\
2\end{array}$ & $\begin{array}{l}39 \cdot 2(29-52) \\
40 \cdot 6(32-45) \\
38 \cdot 7(6-64) \\
34 \cdot 1(26-42)\end{array}$ & $\begin{array}{c}30(9-48) \\
45 \cdot 3(8-96) \\
34 \cdot 7(4-88) \\
57 \cdot 6(16-96)\end{array}$ & $\begin{array}{l}0.5(0-2) \\
1 \cdot 5(0-7) \\
2 \cdot 4(0-25) \\
1 \cdot 1(0-6)\end{array}$ & $\begin{array}{r}(7 \cdot 15 \cdot 9-9 \cdot 1) \\
8 \cdot 8(5 \cdot 2-13 \cdot 2) \\
8 \cdot 1(4 \cdot 3-16 \cdot 0) \\
7 \cdot 1(5 \cdot 2-11 \cdot 1)\end{array}$ & $\begin{array}{l}3 \cdot 7(1-7) \\
2 \cdot 8(1-5) \\
2 \cdot 0(1-10) \\
3 \cdot 2(1-8)\end{array}$ & $\begin{array}{c}32(29-35) \\
32 \cdot 5(31-34) \\
32 \cdot 5(30-35) \\
32 \cdot 5(31-35)\end{array}$ & $\begin{array}{c}42 \cdot 1(10-127) \\
386 \cdot 8(120-740) \\
1199 \cdot 8(400-2040) \\
3224 \cdot 0(1680-6200)\end{array}$ & $\begin{array}{l}0 \\
\text { I } \\
\text { II } \\
\text { III }\end{array}$ \\
\hline
\end{tabular}


day or two before the blood samples were taken had falsely high levels of serum iron and total iron-binding capacitv.

\section{Discussion}

Patients on maintenance haemodialysis become iron-depleted and may require iron therapy. The exact amount of iron needed and the best route of administration are, however, uncertain It has been suggested that oral iron therapy is inconsistent in its effects and that parenteral iron therapy should be given (Carter et al., 1969). Others have found that the absorption of inorganic iron is normal in chronic renal failure (Eschbach et al., 1970 ) and that oral iron is as effective as parenteral iron (Brozovich et al., 1971). The amount of blood loss and hence the amount of iron needed varies with individual patients. Because of these uncertainties and because anaemia in these patients may also be due to other causes, estimation of body iron stores is necessary at regular intervals to assess the need for iron therapy.

Our results show that serum ferritin correlates well with bone marrow iron stores in patients with chronic renal failure on maintenance haemodialysis. This estimation is more convenient than bone marrow biopsy, the amount of blood required being less than $1 \mathrm{ml}$, so that repeated estimations at frequent intervals are feasible.
The regular maintenance iron injections which these patients received provided more iron than most of them needed. A few were iron deficient despite this therapy. Whether this was because these patients omitted iron injections or because they had excessive iron loss is uncertain. With regular serum ferritin assays, however, the iron requirements of each patient can be properly assessed and maintained and those patients with excessive haemorrhage or failing to take iron therapy are easily identified.

\section{References}

Addison, G. M., et al. (1972). Fournal of Clinical Pathology, 25, 326. Brozovich, B., et al. (1971). British Medical fournal, 1, 695.

Carter, R. A., Hawkins, J. B., and Robinson, B. H. B. (1969). British Medical fournal, 3,206.

Crockett, R. E., et al. (1968). In Proceedings of IV Conference of European Dialysis and Transplant Association, p. 17

Dialysis and Transplant Association, p. 17.
Dacie, J. V., and Lewis, S. M. (1963). Practical Haematology, 3rd. edn., London, Churchill.

Edwards, M. S., Pegrum, G. D., and Curtis, J. R. (1970). Lancet, 2, 491.

Eschbach, J. W., Cook, J. D., and Finch, C. A. (1970). Clinical Science, 38, 191 .

acobs, A., et al. (1972). British Medical fournal, 4, 206

Moorhead, J. F., Baillod, R. A., and Hopewell, J. P. (1970). In Proceedings of 4th Irternational Congress on Nephrology, ed. N. Alwall, F. Berglund, and B. Josephson, vol. 3, p. 131. Basle, Karger.

Walters, G. O., Miller, F. M., and Worwood, M. J. (1973). Fournal of Clinical Pathology, 26, 770 .

Wright, F. K., Goldsmith, H. J., and Hall, S. M. (1969). In Proceedings of $V$ Conference of European Dialysis and Transplant Association, p. 179.

\section{Summary}

Immunological studies were performed on a woman with severe pre-eclamptic toxaemia in a second pregnancy. This pregnancy followed a normal twin pregnancy by a different father four years earlier. Both fathers were also studied.

In the mixed lymphocyte culture the patient's lymphocytes reacted eight times as strongly against father 2's cells as against those from father 1. If studies along these lines are performed when a woman has toxaemic and non-toxaemic pregnancies by different fathers information may be obtained on immunogenetic aetiological factors which may be of more value than that derived from the study of large unselected populations.

\section{Introduction}

It has long been postulated that immunogenetic incompatibility may underlie at least some cases of pre-eclampsia (Dienst, 1905; Penrose, 1946, 1947; Platt et al., 1958). Scott (1958) indicated how immunological and non-immunological factors

\footnotetext{
Department of Obstetrics and Gynaecology, University of Leeds,
Leeds LS2 9NG

JILLIAN A. NEED, M.R.c.o.G., Research Assistant
}

could operate through a common mechanism. Stevenson et al. (1971) studied monozygous and dizygous twin pregnancies in inbred communities in the Middle East and provided evidence to suggest that pre-eclampsia was commoner when mother/ conceptus immunogenetic disparity was greatest.

A rare opportunity arose to assess the possible role of immunogenetic factors in a complex "family unit." The mother had had two pregnancies by separate fathers. The first, a multiple gestation, was uncomplicated, while the second, a singleton gestation, was associated with severe pre-eclampsia. Both fathers were available and willing to co-operate in the study.

\section{Case Report}

The mother had an uneventful twin pregnancy by father 1 when aged 20. No hypertension was recorded during the course of regular antenatal care, and she delivered twin boys weighing $2250 \mathrm{~g}$ and $2500 \mathrm{~g}$ at 37 weeks gestation. The placenta and membranes were recorded as monochorionic by an obstetric pathologist; both twins were blood group A rhesus negative and on this evidence they were regarded as monozygotic. She was subsequently divorced. In her second pregnancy by father 2 when she was 24 her initial blood pressure was $120 / 80 \mathrm{~mm} \mathrm{Hg}$ at eight weeks gestation, and it remained normal until 32 weeks, when she was admitted to hospital with a blood pressure of $150 / 100 \mathrm{~mm} \mathrm{Hg}$. Progressive albuminuria to $5 \mathrm{~g} / \mathrm{l}$ developed and her blood pressure rose to $170 / 120 \mathrm{~mm} \mathrm{Hg}$ followed by the onset of severe headaches and epigastric pain at 33 weeks gestation. Protoveratrine A and B (Puroverine, Sandoz) was infused intravenously by a log-increment pump to control the hypertension, and delivery was instituted by amniotomy and oxytocin infusion because of imminent eclampsia. A girl (1570 g) was delivered with an Apgar score of 1 who survived less than one hour as spontaneous respiration never became established. The mother's blood pressure settled to $120 / 80 \mathrm{~mm} \mathrm{Hg}$ 